\title{
Determinants of Brand Loyalty : Survey of Wardah Cosmetics Consumer in Jabodetabek, Indonesia
}

\author{
Rina Adi Kristianti $1^{*}$, Margarita ${ }^{2}$ \\ ${ }^{1,2}$ Economics Faculty, Tarumanagara University, Jakarta, Indonesia \\ *Corresponding author. Email: rinak@fe.untar.ac.id
}

\begin{abstract}
This study tries to explore the determinants of Wardah cosmetics brand loyalty in Jabodetabek Indonesia. The independent variable is product quality, service quality, promotion and customer satisfaction. A sample of 100 respondents in Jabodetabek area \& the sampling technique is convenience sampling (which includes whoever is found in accordance with the focus of research). The technique to get data is questionnaire, the scale used is a Likert scale where the answers are given a score of one to five. The results showed that product quality \& consumer satisfaction had a significant effect on Wardah brand cosmetic loyalty while service quality and promotion had no significant effect on Wardah cosmetics brand loyalty.
\end{abstract}

Keywords: brand loyalty, Wardah cosmetics, respondents, Jabodetabek

\section{INTRODUCTION}

Wardah is a halal icon cosmetics that was founded by PT Paragon Technology and Innovation since 1995. About 20 years after Wardah's presence, global trends show high demand for halal-labeled products. This request comes not only from Muslim communities, but also non-Muslims who have made halal products a lifestyle because halal labels are considered to be able to guarantee the quality and safety of products (https://pressrelease.kontan.co.id/ release). Wardah's development in the first half of 2016, Wardah grew above the industry average (above $20 \%$ for make up products) (https://www.republika.co.id/berita/ ekonomi/makro). This continues to grow quite significantly, in 2018 Wardah growth reached $30 \%$ but only number one in the make up and moisturizer category. Although foreign brands (which already have factories in Indonesia) control $80 \%$ of the Indonesian cosmetics market, in 2019 and in the long term, Wardah aims to expand its market share in all cosmetic categories. (https: www.republika.co.id/berita/ekonomi/porpor).The success of Wardah cosmetics to increase its growth from 2016 to the present, of course is inseparable from the many customers who are loyal to this brand. Brand loyalty provides significant benefits for the company, loyal customers will give a positive attitude such as a repeat purchase or positive recommend so that other customers will be interested in buying the product. This becomes Wardah's company duty to increase customers who are loyal to their products.

Previous researchers have explored many determinants of brand loyalty for cosmetic products. Gillani, et al [9] examined the factors that influence cosmetic brand loyalty in Pakistan. These factors include brand name, price, purchase decision, quality, store environment, design, promotion, expiration date, raw materials used. The sample consisted of 95 respondents, the results showed brand name, price, purchase decision, quality, store environment, design, promotion, expired date and the raw materials used had a significant effect on brand loyalty.

Parmar (2014) examined the determinants of cosmetic brand loyalty in India. Factors studied were marketing with celebrities, brand loyalty programs, brand names, prices, product quality, design, promotion. The sample consisted of 113 respondents, the results showed that brand name, price, marketing with celebrities and brand loyalty programs significantly influence brand loyalty. Upamannyu \& Bhakar (2014) examined the effect of consumer satisfaction on brand image and consumer loyalty in Gwalior India. A sample of 250 respondents and data processing using AMOS16. The results of the study prove that consumer satisfaction is directly related to brand image, customer satisfaction is not directly related to brand loyalty, brand image is proven as a mediating variable between customer satisfaction and brand loyalty. Kitrungpaiboon \& Kim [13] examined the determinants of brand loyalty in Bangkok. These factors include word of mouth, perceived value, convenience and satisfaction. The sample consisted of 384 respondents, the results were word of mouth, perceived value, convenience and satisfaction had a significant effect on brand loyalty.

Chinomona \& Maziriri [6] examined the effect of brand awareness, brand associations and product quality on cosmetic brand loyalty in men in South Africa. The sample consisted of 150 respondents, the results showed that brand awareness and product quality significantly influence brand loyalty. Kalaimani \& Sowmiya [11] examined the determinants of cosmetic brand loyalty in India. Factors studied were quality, brand name, price, packaging, ease of use and product availability. A sample of 50 respondents, the results show that quality, brand name and ease of use are the most important factors affecting brand loyalty. 
This research will focus on factors that influence Wardah brand loyalty, namely product quality, service quality, promotion and customer satisfaction. The selection of the four variables that most closely matches the characteristics of Wardah products so that these four variables are thought to most influence Wardah cosmetic loyalty. From the results of this study, it is expected to provide input to Wardah companies, how to manage these factors namely product quality, service quality, promotion and customer satisfaction to increase the number of customers loyal to the Wardah brand.

\section{LITERATURE REVIEW}

\subsection{Brand and Brand Loyalty}

Brand (trademark) is the name, term, sign, symbol, design or combination which constitutes the identity of a company's product or service that distinguishes it from competitors. Customers see the brand is important from the product and the brand can add value to the product sale (Kotler \& Armstrong [17]). Consumers will have more trust in famous brands than unknown brands. Famous brands will attract consumers to buy and the possibility of repurchasing and minimizing the cost of switching to another brand (Cadogan \& Foster, [5]). Brand loyalty is related to increasing and maintaining a company's market share Increasing and maintaining market share is the key to a long-term profit strategy. (Jacoby and Chestnut, [10]). Ryan et al [22] state that loyal consumers will only buy the same brand in a certain period even though there are many other brands available in the market, so one measure of brand loyalty is the number of repeat purchases made by consumers. Further stated based on previous research proves that loyal customers will spend more money to buy products than customers who are not loyal, and always talk about the positive side of the product so that loyal customers are consumers who are very valuable to the company. (Ganesh et al., [8], Zeithaml et al., [26])

\subsection{Product Quality and Brand Loyalty}

Product quality is a feature or characteristic of a product or service that can satisfy the desires of consumers or product quality related to something that is suitable for use or meets the requirements. (Russell \& Taylor, [21]). Furthermore according to Akrani [2], product quality are some of the features that can meet the desires of consumers and provide customer satisfaction with product improvements eliminate deficiencies and defects of the product or service. Consumers when buying a product, product quality is expected to match or exceed expectations.

There are some products that provide poor quality, this is contrary to their expectations, causing disappointment. This proves whether or not a quality product affects consumer decisions to be loyal in using the product. Product quality that consumers are looking for from a cosmetic product, among others, are durable on the skin, available in various colors that meet consumer tastes, cosmetics use natural ingredients, safe to use on the skin. If all the qualities of cosmetics have met the desires of consumers, they will be loyal to the product. Research conducted by Chinomona \& Maziriri [6]; Kalaimani \& Sowmiya [11] prove that product quality has a significant positive effect on brand loyalty.

H1: Product quality has a positive effect on Wardah cosmetic brand loyalty

\subsection{Service Quality and Brand Loyalty}

Quality of service including personal selling, direct involvement and interaction between salespeople and buyers. Buyers like to shop at certain stores because they like the services of their sales force. (Khraim, [12]). The quality of service is preferred, such as salespeople who have adequate knowledge about the product, want to help consumers choose the right product, are friendly and polite to make consumers feel comfortable with the services provided, This feeling of comfort is one indicator that makes consumers buy at the same place repeatedly. Service quality has a significant positive effect on brand loyalty, this is evidenced by research conducted by Khraim [12].

$\mathrm{H} 2$ : Service quality has a positive effect on Wardah cosmetic brand loyalty

\subsection{Promotion and Brand Loyalty}

Clow [7] states promotion is an important element for developing marketing strategies. Promotion is used to communicate with consumers in offering products and promotion is one way to increase consumer purchases. Rafique, et al [20] argue that promotion is a way to communicate with consumers, so the company tries to use some of the best promotional techniques that are appropriate to the characteristics of its products. Promotion strategies are needed so that the product can be glanced at and then bought by consumers. By promoting the product, the product will be well known by the public. Abiodun [1] states promotion is directly related to product sales because through promotion, consumers will be motivated to buy the product. Pope [18] proves that repetition of advertisements will sharpen consumers' memories of the product and buy repeatedly.

Usually the promotion that is carried out will attract the attention of consumers, cause the desire to buy back the product. Even to increase consumer loyalty, some products use well-known celebrities. Consumer interest in these products is also based on campaigns for "halal" products and often products are promoted through social media. So that promotion has a significant positive effect on brand loyalty, this is evidenced by Ghillani, et al [9]; Parmar [17]. 
H3: Promotion has a positive effect on Wardah cosmetic brand loyalty

\subsection{Consumer Satisfaction and Brand Loyalty}

Kotler \& Armstrong [14] states consumer satisfaction is related to product performance compared to consumer expectations. When product performance exceeds their expectations, consumers will feel satisfied. Conversely, if product performance is below their expectations, consumers will feel disappointed. Omanga [16] states that customer satisfaction is a reaction (happy or disappointed) after consumers evaluate the value of the product received with expectations. Consumer satisfaction is an important part of brand loyalty because it causes repeat buying and recommended buying. Bowen \& Chen [4] states that if customer satisfaction increases, brand loyalty will increase sharply. This is supported by research conducted Nezakati, et al [15]; Kitrungpaiboon \& Kim [13].

H4: Customer satisfaction has a positive effect on Wardah cosmetic brand loyalty

\subsection{Prior Research}

Several previous researchers have explored determinants of cosmetic brand loyalty. Below is a summary:

\section{Table 1 Previous Research on Cosmetic Brand}

Loyalty

\begin{tabular}{|l|l|l|l|}
\hline No & Year & Researchers & \multicolumn{1}{|c|}{ Results } \\
\hline 1 & 2017 & $\begin{array}{l}\text { Chinomona } \\
\text { \& Maziriri } \\
{[6]}\end{array}$ & $\begin{array}{l}\text { Brand awareness and } \\
\text { product quality have a } \\
\text { significant effect on } \\
\text { brand loyalty. }\end{array}$ \\
\hline 2 & 2017 & $\begin{array}{l}\text { Kalaimani \& } \\
\text { Sowmiya } \\
{[11]}\end{array}$ & $\begin{array}{l}\text { Quality, brand name } \\
\text { and ease of use are the } \\
\text { most important factors } \\
\text { that affect brand loyalty }\end{array}$ \\
\hline 3 & 2017 & Puri [19] & $\begin{array}{l}\text { Brand image has been } \\
\text { proven to influence } \\
\text { consumer satisfaction } \\
\text { and brand loyalty, } \\
\text { customer satisfaction } \\
\text { has been proven to } \\
\text { influence brand loyalty. }\end{array}$ \\
\hline 4 & 2016 & $\begin{array}{l}\text { Kitrungpaibo } \\
\text { on \& Kim } \\
{[13]}\end{array}$ & $\begin{array}{l}\text { Word of mouth, } \\
\text { perceived value, } \\
\text { convenienxe, have a } \\
\text { satisfaction have } \\
\text { significant effect on } \\
\text { brand loyalty. }\end{array}$ \\
\hline 5 & 2014 & $\begin{array}{l}\text { Brand names, prices, } \\
\text { marketing with } \\
\text { celebrities and brand } \\
\text { loyalty programs have } \\
\text { proven to have an effect } \\
\text { on brand loyalty. }\end{array}$ \\
\hline
\end{tabular}

\begin{tabular}{|c|c|c|c|}
\hline 6 & 2014 & $\begin{array}{l}\text { Upamannyu } \\
\text { \& Bhakar } \\
{[24]}\end{array}$ & $\begin{array}{l}\text { Consumer satisfaction is } \\
\text { directly related to brand } \\
\text { image, customer } \\
\text { satisfaction is not } \\
\text { directly related to brand } \\
\text { loyalty, brand image is } \\
\text { proven as an } \\
\text { intervening variable on } \\
\text { consumer satisfaction } \\
\text { and brand loyalty. }\end{array}$ \\
\hline 7 & 2013 & $\begin{array}{l}\text { Gillani, et al } \\
\text { [9] }\end{array}$ & $\begin{array}{lr}\text { Brand name, } & \text { price, } \\
\text { purchase } & \text { decision, } \\
\text { quality, } & \text { store } \\
\text { environment, design, } \\
\text { promotion, expiration } \\
\text { date and raw materials } \\
\text { used have a significant } \\
\text { effect on brand loyalty. }\end{array}$ \\
\hline 8 & 2013 & $\begin{array}{l}\text { Nezakati, et } \\
\text { al [15] }\end{array}$ & $\begin{array}{l}\text { Perceived value and } \\
\text { customer satisfaction } \\
\text { have been proven to } \\
\text { influence brand loyalty. }\end{array}$ \\
\hline 9 & 2012 & $\begin{array}{l}\text { Altaf, et al } \\
{[3]}\end{array}$ & $\begin{array}{lr}\text { Brand credibility, brand } \\
\text { awareness, } \\
\text { association, prand } \\
\text { quality, perceived } \\
\text { knowledge } \\
\text { positive product } \\
\text { with brand loyalty } \\
\end{array}$ \\
\hline 10 & 2011 & Kraim [12] & $\begin{array}{l}\text { All independent } \\
\text { variables are proven to } \\
\text { affect brand loyalty } \\
\text { except design. }\end{array}$ \\
\hline
\end{tabular}

\section{RESEARCH METHODS}

\subsection{Population and Sampling Techniques}

The population in this study were women using Wardah cosmetics who lived in Jabodetabek (Jakarta, Bogor, Depok, Tangerang and Bekasi). The sampling technique is convience sampling which includes whoever is found in accordance with the focus of the study (Sekaran \& Bougie, [23]). The sample in this study amounted to 100 people.

\subsection{Variables and Indicators}

Presented below are the research variables, operational definitions, indicators and question item

Table 2 Definitions of Variables and Indicators

\begin{tabular}{|c|c|c|}
\hline No & Variables & Indicators \\
\hline 1 & $\begin{array}{l}\text { Brand } \\
\text { loyalty }\end{array}$ & $\begin{array}{l}\text { 1. Repurchase } \\
\text { 2. Recommendations } \\
\text { 3. Talking strengths } \\
\text { 4. Brand switching }\end{array}$ \\
\hline 2 & Product & 1. Long lasting on the skin \\
\hline
\end{tabular}




\begin{tabular}{|l|l|l|}
\hline & quality & $\begin{array}{l}\text { 2. Color availability } \\
\text { 3. Safe to use } \\
\text { 4. The use of natural ingredients }\end{array}$ \\
\hline 3 & Service & $\begin{array}{l}\text { 1. Practiced } \\
\text { 2. Adequate knowledge } \\
\text { 3. Help consumers } \\
\text { 4. Friendly \& polite } \\
\text { 5. Clean and neat }\end{array}$ \\
\hline 4 & Promotion & $\begin{array}{l}\text { 1. Attract attention } \\
\text { 2. Advertising with celebritis } \\
\text { 3. Halal product } \\
\text { 4. Social media }\end{array}$ \\
\hline 5 & $\begin{array}{l}\text { Consumer } \\
\text { satisfaction }\end{array}$ & $\begin{array}{l}\text { 1. Feeling happy } \\
\text { 2. Conformity of expectations } \\
\text { 3. Meet the needs }\end{array}$ \\
\hline
\end{tabular}

\section{RESULTS}

\subsection{Most Preferred Product}

$f$ the several product items that are frequently purchased by respondents, there are several products that rank first, the most preferred products. The data is below:

Table 3 The Most Preferred Product of Wardah Cosmetic Brand Loyalty Respondents

\begin{tabular}{|c|l|l|}
\hline No & Most Preferred Product & \multicolumn{1}{c|}{ Total } \\
\hline 1 & Lipstick & 47 people \\
\hline 2 & Powder & 13 people \\
\hline 3 & Foundation & 11 people \\
\hline 4 & Make up base & 9 people \\
\hline 5 & Face wash & 8 people \\
\hline 6 & Acne series & 3 people \\
\hline 7 & Micellar water & 3 people \\
\hline 8 & Eyeshadow & 2 people \\
\hline 9 & Aloe vera gel & 2 people \\
\hline 10 & Perfume & 1 people \\
\hline 11 & Eyeliner remover & 1 people \\
\hline & TOTAL & 100 people \\
\hline
\end{tabular}

Table 3 above shows that Wardah's most preferred cosmetics number one is lipstick with a total of 47 people, number two is powder with a total of 13 people, number three is foundation with a total of 11 people, number four is make-up base with a total of 9 people, number five is facial soap with a total of 8 people, number six is acne series with a total of 3 people, number seven is micellar water with a total of 3 people, number eight is eyeshadow with a total of 2 people, number nine is aloe vera gel with a total of 2 people, number ten is perfume for 1 person and number eleven is eyeliner remover for 1 person.

\subsection{Validity Test Result}

Below are presented the results of the validity test

Table 4 Testing the Validity of Brand Loyalty

\begin{tabular}{|l|l|l|}
\hline Question Items & $\begin{array}{l}\text { Corrected Item - } \\
\text { Total correlation }\end{array}$ & Conclusion \\
\hline Item 1 & 0,769 & Valid \\
\hline Item 2 & 0,713 & Valid \\
\hline Item 3 & 0,760 & Valid \\
\hline Item 4 & 0,681 & Valid \\
\hline
\end{tabular}

Table 4 above, it can be seen that the corrected items from question items $1-4>0.30$ so that questions 1 - 4 are asked validly. Below is presented the results of the validity test of product quality variables with question items $5-8$.

Table 5 Testing the Validity of Product Quality

\begin{tabular}{|l|l|l|}
\hline Question Items & $\begin{array}{l}\text { Corrected Item - } \\
\text { Total correlation }\end{array}$ & Conclusion \\
\hline Item 5 & 0,699 & Valid \\
\hline Item 6 & 0,582 & Valid \\
\hline Item 7 & 0,760 & Valid \\
\hline Item 8 & 0,716 & Valid \\
\hline
\end{tabular}

From table 5 above, it can be seen that the corrected items from question items $5-8>0.30$ so that questions $5-8$ are asked validly. Below is presented the test results of the validity of service quality variables with question items 913.

Table 6 Testing the Validity of Service Quality

\begin{tabular}{|l|l|l|}
\hline Question Items & $\begin{array}{l}\text { Corrected Item - } \\
\text { Total correlation }\end{array}$ & Conclusion \\
\hline Item 9 & 0,792 & Valid \\
\hline Item 10 & 0,827 & Valid \\
\hline Item 11 & 0,752 & Valid \\
\hline Item 12 & 0,822 & Valid \\
\hline Item 13 & 0,695 & Valid \\
\hline
\end{tabular}

Table 6 above, it can be seen that the corrected items from question items $9-13>0.30$ so that questions $9-13$ are valid. Below is presented the results of the validity test of promotional variables with question items no $14-18$.

Table 7 Testing the Validity of Promotion

\begin{tabular}{|l|l|l|}
\hline Question Items & $\begin{array}{l}\text { Corrected Item - } \\
\text { Total correlation }\end{array}$ & Conclusion \\
\hline Item 14 & 0,713 & Valid \\
\hline Item 15 & 0,648 & Valid \\
\hline Item 16 & 0,727 & Valid \\
\hline Item 17 & 0,638 & Valid \\
\hline Item 18 & 0,668 & Valid \\
\hline
\end{tabular}

Table 7 above, it can be seen that the corrected items of question items $14-18>0.30$ so that questions $14-18$ are valid. Below is presented the results of the validity test of 
the customer satisfaction variable with the item questions number 19-22.

Table 8 Testing the Validity of Customer

Satisfaction

\begin{tabular}{|l|l|l|}
\hline Question Items & $\begin{array}{l}\text { Corrected Item - } \\
\text { Total correlation }\end{array}$ & Conclusion \\
\hline Item 19 & 0,814 & Valid \\
\hline Item 20 & 0,825 & Valid \\
\hline Item 21 & 0,860 & Valid \\
\hline Item 22 & 0,873 & Valid \\
\hline
\end{tabular}

Table 8 above, it can be seen that the corrected item of the question items 19-22>0.30 so that the question items 1922 were asked were valid.

\subsection{Reliability Test}

Below is presented the reliability test for each variable using Cronbach Alpha. If Cronbach Alpha> 0.60, it can be said that all questions on all variables are reliable.

Table 9 Reliability Testing

\begin{tabular}{|l|l|l|}
\hline \multicolumn{1}{|c|}{ Variables } & Cronbach Alpha & Conclusion \\
\hline $\begin{array}{l}\text { Brand loyalty } \\
(Y)\end{array}$ & 0,791 & Reliable \\
\hline $\begin{array}{l}\text { Product } \\
\text { quality(X1) }\end{array}$ & 0,773 & Reliable \\
\hline $\begin{array}{l}\text { Service quality } \\
(\mathrm{X} 2)\end{array}$ & 0,800 & Reliable \\
\hline Promotion(X3) & 0,769 & Reliable \\
\hline $\begin{array}{l}\text { Customer } \\
\text { satisfaction (X4) }\end{array}$ & 0,827 & Reliable \\
\hline
\end{tabular}

Table 9 above shows that the Cronbach Alpha value for each variable is $>0.60$ so it can be concluded that all the questions on the five variables are reliable.

\section{4. $R$ Square Test}

Below are presented the results of the R Square test

Table 10 Result of $R$ square test

\begin{tabular}{|l|c|r|r|}
\hline Model & \multicolumn{1}{|c|}{$\mathbf{R}$} & \\
& $\mathbf{R}$ & Square & Adjusted R Square \\
\hline 1 &, $672^{\mathrm{a}}$ &, 452 &, 429 \\
\hline
\end{tabular}

Table 10 above shows the R Square value of $45.2 \%$, which means $45.2 \%$ variation of Wardah cosmetics brand loyalty can be explained by product quality, service quality, promotion and customer satisfaction. While the remaining $54.8 \%$ is explained by other variables outside this study. Below, the hypothesis test results are presented.

\subsection{Hypothesis Testing}

Hypothesis testing can be seen through the t test where if the $\mathrm{p}$ value $<\alpha$ then the hypothesis is accepted. Below is presented the results of the $t$ test.

Table 11 Result of $t$ test

\begin{tabular}{|c|c|c|c|c|c|}
\hline \multirow{2}{*}{ Model } & \multicolumn{2}{|c|}{$\begin{array}{c}\text { Unstandardized } \\
\text { Coefficients } \\
\end{array}$} & \multirow{2}{*}{$\begin{array}{c}\text { Standardized } \\
\text { Coefficients } \\
\text { Beta }\end{array}$} & \multirow[b]{2}{*}{$\mathbf{t}$} & \multirow[b]{2}{*}{ Sig } \\
\hline & B & $\begin{array}{l}\text { Std } \\
\text { Error }\end{array}$ & & & \\
\hline $1 \mathrm{C}$ & ,386 & $\begin{array}{r}1,94 \\
4 \\
\end{array}$ & & ,198 & $\begin{array}{r}, 84 \\
3 \\
\end{array}$ \\
\hline $\mathrm{X} 1$ & ,422 & ,139 &, 327 & 3,039 & $\begin{array}{r}, 00 \\
3\end{array}$ \\
\hline $\mathrm{X} 2$ & 051 & ,091 & ,056 & ,569 & $\begin{array}{r}, 57 \\
1\end{array}$ \\
\hline X3 & ,040 & ,079 & 043 & ,503 & $\begin{array}{r}, 61 \\
6\end{array}$ \\
\hline X4 & ,340 & ,120 &, 341 & 2,822 & $\begin{array}{r}, 00 \\
6\end{array}$ \\
\hline
\end{tabular}

Table 11 above it appears that product quality has a significant positive effect on brand loyalty of Wardah cosmetics, this is indicated by the $\mathrm{p}$ value of $0.003<\alpha$ (0.01)._Service quality has no significant effect on Wardah brand cosmetic loyalty, this is indicated by the $p$ value of $0.571>\alpha(0.05)$._Likewise the promotion had no significant effect on Wardah brand cosmetic loyalty with a $\mathrm{p}$ value of $0.616>\alpha(0.05)$. While the last variable is consumer satisfaction significantly positive effect on brand loyalty Wardah cosmetics with a $\mathrm{p}$ value of $0.006<\alpha$ $(0.01)$. Below is a summary.

Table 12 Summary of research hypothesis testing

\begin{tabular}{|c|c|c|}
\hline $\begin{array}{c}\text { Research } \\
\text { Hypothesis }\end{array}$ & P value & Conclusion \\
\hline Hypothesis 1 & 0,003 & Accepted \\
\hline Hypothesis 2 & 0,571 & Rejected \\
\hline Hypothesis 3 & 0,616 & Rejected \\
\hline Hypothesis 4 & 0,006 & Accepted \\
\hline
\end{tabular}

Table 12 shows that the first hypothesis namely product quality has a positive effect on brand loyalty is proven. This is consistent with research conducted by Chinomona \& Maziriri [6]; Kalaimani \& Sowmiya [11]. The quality of the products offered by Wardah cosmetics can fulfill consumer desires so that consumers continue to make repeat purchases and become loyal to this product.Of the product quality items that have the greatest influence on brand loyalty, Wardah cosmetics are available in a variety of colors and meet consumer tastes and safe for the skin. 
The second hypothesis which states that service quality has a positive effect on brand loyalty is not proven. This is not in accordance with research conducted by Khraim [12]. The services provided primarily from sales promotion girls are not a factor for consumers to be loyal to the product. This can be possible for consumers to perceive that the salesperson's knowledge of the product is still lacking, they do not help consumers to choose the right product. Another thing that is a factor why service quality does not have a significant effect on brand loyalty is consumers to have complete information about this product and to follow the latest product trends so that consumers do not really need the help of sales promotion girl considering this is not the first purchase.

The third hypothesis which states that promotion has a positive effect on brand loyalty is not proven. This is not in accordance with research conducted by Ghillani, et al [9]; Parmar [17]. Promotion is not an important factor for consumers to be loyal to this product. Respondents perceive that the promotion carried out by Wardah cosmetics does not attract them to buy back, the lack of use of celebrities to convince repurchase interest, the lack of promotion through mass media. Another factor that causes promotion does not have a significant effect on brand loyalty is possible for consumers to buy over and over again so no more promotion is needed to make consumers loyal to this product. The program that is more needed to maintain consumer loyalty is the brand loyalty program (Parmar, [17]).

The fourth hypothesis which states that customer satisfaction has a positive effect on brand loyalty is proven. This is consistent with research conducted by Bowen \& Chen [4]; Nezakati, et al [15]; Kitrungpaiboon \& Kim [13] ; Puri [19]. The results of this study prove that consumers feel satisfied and not dissappointed after using this product so that they make repeat purchases and are loyal to this product.

\section{CONCLUSIONS AND IMPLICATIONS}

\subsection{Conclusions}

a. The results of this study prove that product quality and customer satisfaction significantly influence the loyalty of Wardah cosmetics brands while service quality and promotion do not significantly influence the loyalty of Wardah cosmetics brands.

b. The main factor of product quality that makes consumers loyal to the Wardah brand is consumers perceive that Wardah cosmetics are available in a variety of colors that meet their tastes and Wardah cosmetics are safe for the skin. 3. The main factor of consumer satisfaction that makes consumers loyal to the Wardah brand is that consumers feel that Wardah cosmetics already fulfill their desires and already feel happy and satisfied after using the product.

\subsection{Managerial implications}

a. From Wardah's cosmetic brand loyalty, it can be seen that consumers rarely talk about their strengths and weaknesses. It is possible that there is a lack of media for communication so that Wardah producers are expected to open more discussion forums and opinions on social media.

b. In terms of service quality, companies must provide more frequent training to salespeople so that they have adequate knowledge of products, can act appropriately to help consumers so that they can better improve their services.

c. From the promotion, it can be seen that companies need to intensify their promotions, use celebrities more often in their promotional activities and more often promote their products through social media.

\subsection{Future research}

a. Need to add a sample size up to 300 respondents.

b. Judging from R Square value which is only $45.2 \%$, it is necessary to add other variables beyond that has a significant effect on brand loyalty including price, packaging, word of mouth, brand loyalty programs.

\section{REFERENCES}

[1] Abiodun, A.O, The impact of advertising on sales volume of a product. University of Applied Sciences, Valkeakoski, 2011.

[2] Akrani, G, What is product quality? Definition meaning importance, 2013, http://kalyancity.blogspot.my/2013/05/what-is-product-qualitydefinition-html.

[3] Altaf, M ; Yousaf, U; Zulfiqar, R \& Aslam, M, Studying brand loyalty in the cosmetics industry. Scientific Journal of Logistic, Vol 8 (4), 2012, pp 327 337

[4] Bowen, J. T \& Chen, S.L, The relationship between customer loyalty and customer satisfaction. International Journal of Contemporary Hospitality Management, Vol 13 (5), 2011, pp 213 - 217.

[5] Cadogan, J.W \& Foster, B.D, Relationship selling and customer loyalty : An empirical investigation. Marketing Intelligent \& Planning, Vol 18 (4), 2000, pp $185-199$

[6] Chinomona, R \& Maziriri, E, T, The influence of brand awareness, brand association and product quality on brand loyalty and repurchase intention: a case of male consumers for cosmetic brands in South Africa. 
Journal of Business \& Retail Management Research, Vol 12 (1), 2017, pp 143 - 154.

[7] Clow, M, Integrated Marketing Communications. Pearson Prentice Hall, New Jersey, USA, 2010.

[8] Ganesh, J; Arnold, M.J \& Reynolds, K.E, Understanding the customer base of service providers : An examination of the differences between switchers and stayers. Journal of Marketing, Vol 64, 2000, pp 65 $-87$

[9] Gillani, S, F; Yousaf, S \& Khan, S, The effect of brand characteristics on brand loyalty : A study of cosmetics products in Peshawar Pakistan. International Review of Basic and Applied Sciences, Vol 1 (1), 2013, pp $1-11$.

[10] Jacoby, J \& Chestnut, R.W, Brand Loyalty Measurement \& Management, John Wiley \& Sons, New York , 1978.

[11] Kalaimani, N \& Sowmiya, A,R,B, Brand loyalty of cosmetic products among youths. Intercontinental Journal of Marketing Research Review, Vol 5 (7), 2017, pp $100-105$.

[12] Khraim, H. S, The influence of brand loyalty on cosmetics buying behavior of UAE female consumers. International Journal of Marketing Studies, Vol 3 (2), 2011, pp123 - 133.

[13] Kitrungpaiboon, K \& Kim, S, Factors affecting brand loyalty to cosmetics product : A case study of Thai consumers in Bangkok, AU-GSB e Journal, Vol 9 (2), 2016, pp $53-61$.

[14] Kotler, Philip dan Armstrong, Gary, Principles of Marketing, 14th edition, Pearson, Prentice Hall, New Jersey, USA, 2017.

[15] Nezakati, H; Yen, C.P \& Akhoundi, M, Antecedens impact on brand loyalty in cosmetics industry. Journal of Applied Sciences, Vol 13 (1), 2013, pp $126-132$

[16] Omanga, L.K, Determinants of brand loyalty in cosmetic products : A case of selected salons in Nyeri Town, Kenyatta University, 2010.

[17] Parmar, S.K.M, A study brand loyalty for cosmetic products among youth. International Journal for Research in Management \& Pharmacy, Vol 3 (6), 2014, pp $9-21$.

[18] Pope, D, Making Sense of Advertisements. (from the making sense of evidence series on history matters:
The US survey on the web), 2009.

[19] Puri, R.M, The effect of brand image on customer satisfaction and customer loyalty for Wardah cosmetic, Universitas Muhammadiyah Surakarta, 2017.

[20] Rafique, M., \& Zafar, Q.U.A, Impact of celebrity advertisement on customers ${ }^{\text {ee }}$ Brand perception and purchase intention. Asian Journal of Business and Management Sciences, Vol 1 (11), 2012, pp 53-67.

[21] Russel, R.S \& Taylor, B.W, Operation Management : Quality \& Competitiveness in A Global Environment, 5 edition, John Willey \& Sons Inc, New Jersey, USA, 2006.

[22] Ryan, M.J; Rayner, R \& Morrison A, Diagnosing customer loyalty drivers. Marketing Research, Vol 11 (2), 1999, pp $18-26$

[23] Sekaran, U \& Bougie, R, Research Methods for Business : A Skill Building Approach. Seventh edition, John Willey \& Sons, UK, 2017.

[24] Upamannyu, N.K \& Bhakar, S, S, The effect of customer satisfaction on brand image and loyalty intention : A study of cosmetic product, International Journal of Research in Business and Technology, Vol 4 (1), 2014, pp $296-307$.

[25] Zaltman, Gerald, dan Wallendorf, Melanie, Consumer Behavior, Second Edition, Englewood Cliffs, New Jersey, Prentice Hall, 1979.

[26] Zeithaml, V.A; Berry, L, L \& Parasuraman, A , The behavioral consequences of service quality. Journal of Marketing, Vol 60 (2), 1996, pp 31 - 46. 